\title{
Evaluation of Phenological Cycles and Thermal Time of Apple Crop Growing at Different Altitudinal Gradients in North Western Himalayas
}

\author{
Aditya $^{1^{*}}$, S. K. Bhardwaj ${ }^{2}$, Sudhir Verma ${ }^{2}$ and Rakesh ${ }^{2}$ \\ ${ }^{1}$ Chandigarh University, Mohali, Punjab (140 413), India \\ ${ }^{2}$ Dr. Y. S. Parmar, University of Horticulture and Forestry, Nauni, Solan (173 230), India
}

\section{Corresponding Author}

Aditya

e-mail: adirana13@gmail.com

\author{
Article History \\ Article ID: IJEP0280 \\ Received in $06^{\text {th }}$ January, 2019 \\ Received in revised form $15^{\text {th }}$ January, 2019 \\ Accepted in final form $21^{\text {st }}$ February, 2019
}

\begin{abstract}
A field study was conducted in 2015 and 2016 to evaluate the phenological cycles and thermal time of apple crop of economic importance growing at different climate represented by varied altitudinal gradients in Himachal Pradesh, India. The experiment was laid out in Randomized Block Design with three altitudinal gradients at 1000-1000 m amsl (gradient I at Bajaura), at 1150-1250 m amsl (gradient I at Seobagh), at $1500-1600 \mathrm{~m}$ amsI (gradient I at Rohru), Bajaura (altitudinal gradient I at 1000-1100 m amsl), Seobagh (altitudinal gradient II at 1150-1250 $\mathrm{m}$ amsl) and Rohru (altitudinal gradient III at 1500-1600 m amsl) and five commercial cultivars as two factors.The air temperature at mid and higher altitudinal gradients ranged from 7.9 to $17.1^{\circ} \mathrm{C}$ and 7.3 and $15.3^{\circ} \mathrm{C}$, which was 1.0 to $1.9^{\circ} \mathrm{C}$ and 2.2 to $3.4^{\circ} \mathrm{C}$ less than the lower altitudinal gradient, respectively. The dormancy break at mid gradient was advanced by 1-3 and 3-6 days in attainment of silver tip stage at higher gradient. All phenophases were significant and negatively correlated to the average air temperature from January to April indicating that higher temperature after the winter rest of plants accelerated the developmental processes and finally led to an advanced timing of spring events. The GDD had a negative correlation with the occurrence of the different phenological stages of apple crop indicating that with increased accumulation of heat the attainment of phenological stages will be advanced. The warming in the early spring (February-April) by $2-4{ }^{\circ} \mathrm{C}$ at lower elevation caused an advancementof the beginning of phenophases by $7-13$ days.
\end{abstract}

Keywords: Correlation, cultivars, dormancy, GDD, temperature

\section{Introduction}

The rate of growth and development of a crop is a function of the energy receipt and thermal regime in any given crop growth season. Environmental conditions play a significant role of modulating the transition from vegetative to generative growth in plants. In terms of climatic indicator variables, air temperatureand precipitation are imperative. The former isparticularly important because it is linked both directlyand indirectly to other physical indicators such as soil temperature, day length (photoperiod) and solar radiation. Temperature in addition acts as a key factor for the seasonal timing of spring phenophases related to foliage and flowering of various plant species (Menzel, 2003). Moreover, the cumulative effect of daily air temperatureover the longer term is an important indicator ofplant growth potential and crop yield (Schwartz et al., 2006). However, the changing climate has considerable impacts on thephenology of temperate plants, with many species showingadvances or delay in the flowering timing in spring season (Parmesan and Yohe, 2003). One of the probable effectsrelating to changing temperature regimes is delay in the commencement of chill accumulation and consequently the fulfilment of chilling requirement. Since bloom and leaf emergence resultfrom at least partially sequential fulfilment of chilling and heat (forcing) requirements, lack of which leads to a later bloom and leafing inspring. Thus, an indirect effect of increasing air temperaturesis the prolongation of the growing season (Chmielewski and Rotzer, 2001) and the modification of the phenological phasesof individual plants.

Temperate fruit crops like apple being deciduous in nature are adapted to temperate regions in which theyovercome large seasonal changes in air temperature.Such adaptation is an outcome of annualgrowth cycle in which all developmental processes are finely tuned with the annualcourse of the growing conditions (Hanninen and Kramer, 2007). However, with the change in the average climatic variables as is evident during the past few decades, the productivity of the fruits in the state is also influenced. Due to the erratic weather conditions some of the parts of the state dominated by apple were now falling low in terms of being commercially productive (Vedwan, 2006).

Knowledge of phenological stages and fruit growth 
development are important requirements for many facets of crop management. The appearance dates of plant phenophases provide basic information for the decision of farmers as regards to some cultivation techniques such as fertilization, irrigation and crop protection techniques. This knowledge can help the selection of the most suitable species or varieties of fruit trees and crops in certain regions crucial for improving cropmanagement, productivity and obtaining better fruit quality with acceptance by the market (Chmielewski, 2003). The use ofthermal units system or Growing Degree Days (GDDs) is another wayto assess the interactions between climate andplant. Hence it becomes important toinvestigate observed changes in the phenology and GDDs so thatfuture predictions can be validated andput into context. Therefore, the present study was conducted to analyse various phenologicalstages and thermal time of apple fruit cultivars for regionalassessment of GDD and temperature as agro-climatic indicators comparative to the suitable altitudinal gradients for apple cropin Himachal Pradesh, India.

\section{Materials and Methods}

\subsection{Experimental sites for apple fruit crop phenology}

The field study was conducted during 2015 and 2016 to evaluate the phenological cycles and thermal time of apple crop growing at different climates represented by varied altitudinal gradients in Himachal Pradesh, India. The investigation was carried out at three different locations in twodistricts of Himachal Pradesh viz., Kullu (Mid-Hills Subhumid-Zone II) and Shimla (High-Hills Wet Temperate- Zone III). Three different bases were considered for the selection of the locations namely, apple growing pockets/ region, climatic conditions and elevation. The altitudinal gradients selected for the study were:Bajaura (altitudinal gradient I at 1000-1100 m amsl), Seobagh (altitudinal gradient II at $1150-1250 \mathrm{~m}$ amsl) and Rohru (altitudinal gradient III at 1500-1600 m amsl).

\subsection{Experimental details}

The experimental material consisted of five important commercial apple cultivarsnamely Royal Delicious, Gale gala, Scarlet Spur, Vance delicious and Red Chiefof uniform size, shapeand about age (15-20 years). The selected trees were erect, medium in size and shoot medium to thick with spreading nature and spaced at $6 \times 6$ meter distance. The experiment was laid out in Randomized Block Design with three altitudinal gradients and five cultivars as treatments for two factors. In total there were $15(3 \times 5)$ treatment combinations which were replicated five timeswith one tree per treatment.

\subsection{Observations recorded}

The observations of phenophasic developmental stages for the study as described by Chapmanand Catlin (1976) were recorded as follows:

- Silver tip: fruit bud scales separated at tip, showing light grey tissue.

- Pink: flower petals elongating, sepals slightly open, petals just visible.

- Bloom: at least $50 \%$ of flowers open, first petals falling.

- Petal fall: after about $75 \%$ of petals have fallen.

- Fruit set: fruit size up to $10 \mathrm{~mm}$; fruit fall after flowering.

The daily weather data with respect to maximum temperature, minimum temperature and rainfall for the year 2015 and 2016 was procured from Regional Horticultural Research Station, Seobagh and India Meteorological Department (IMD) at Shimla.

\subsection{Calendar days and GDD calculation}

Detailed phenological observations were made during two growing seasons (2015 and 2016) in a frequency depending on the stage, from twoto three times per week to once per fortnight. To record the duration of every phenologicalstage, four random shoots were selected in all directions of the canopy at each site. In order to account for variability within a shoot, all the branches in the selected shoot were evaluated and average observation was recorded. The beginning of the year i.e. $1^{\text {st }}$ January was used as an approximation of the beginning of the development across the study area (Orlandi et al., 2015). The consequent number of calendar days to attain each phenological stage was calculated. In order to compare phenological stages between years in terms of accumulation of heat duringthe season, growing degree days (GDD) were also calculated. The first clearly identifiable stage in apple (silver tip), sub-temperate fruits (pink) and mango (big bud) was used as a biofix for the onset of growth with GDD accumulated starting January 1. Accumulated GDD werecalculated from weather data (maximum and minimum temperature) of the respective site using the following formula.

$\mathrm{GDD}=\sum_{i=1}^{m}(\mathrm{~T} i$-Tbase $)$

$T i=\left(T_{\max }+T_{\min }\right) / 2$

$\mathrm{Ti}=$ mean air temperature $\left({ }^{\circ} \mathrm{C}\right)$ on the $\mathrm{i}^{\text {th }}$ day of the growing season, $T_{\max }=$ maximum temperature $\left({ }^{\circ} \mathrm{C}\right), \mathrm{T}_{\min }=$ minimum temperature $\left({ }^{\circ} \mathrm{C}\right)$ and Tbase $=$ base or threshold temperature.

The base temperature of $4^{\circ} \mathrm{C}$ considered for apple fruit crop (Singh and Bhatia, 2012). Developmental stageof each plant recorded was compared between locations, growing seasons and cultivars.

\section{Results and Discussion}

\subsection{Effect of altitudinal gradient on calendar days and GDD required for silver tip stage}

The data presented in Table 1 indicated that apple fruit crop growing at different altitudinal gradients exhibited significant variations in attainment of silver tip stage. The 
Table 1: Effect of altitude-wise air temperature variations on calendar days for silver tip stage in different cultivars of apple fruit crop

\begin{tabular}{lcccc}
\hline Cultivar & \multicolumn{4}{c}{ Altitudinal gradient } \\
\cline { 2 - 5 } & $\begin{array}{c}1000- \\
1200 \mathrm{~m} \\
\text { amsl (I) }\end{array}$ & $\begin{array}{c}1200- \\
1400 \mathrm{~m} \\
\text { amsl (II) }\end{array}$ & $\begin{array}{c}1400- \\
\text { amsl (III) }\end{array}$ & Mean \\
\hline Royal delicious & 54.0 & 58.1 & 63.9 & 58.7 \\
Red delicious & 52.5 & 56.3 & 60.9 & 56.6 \\
Red chief & 46.6 & 53.2 & 58.8 & 52.9 \\
Vance delicious & 51.0 & 55.0 & 59.5 & 55.2 \\
Scarlet spur & 45.1 & 51.5 & 57.8 & 51.5 \\
Mean & 49.8 & 54.8 & 60.2 & 54.9 \\
CD ( $p=0.05$ ) & & & & \\
Year & 0.3 & & & \\
Location & 0.3 & & & \\
Cultivar & 0.4 & & & \\
Yearxlocation & 0.5 & & & \\
Yearxcultivar & 0.6 & & & \\
Cultivarx & 0.8 & & & \\
location & & & & \\
\hline
\end{tabular}

Year×cultivar×altitudinal gradient NS

perusal of data further showed that accomplishment of this stage also varied with all the selected cultivars of apple crop as well.Number of days to attain silver tip stage in apple growing regions indicated that on average minimum days of 49.8 were required to attain silver tip stage at altitudinal gradient I followed by 54.8 and 60.2 days at gradient II and III, respectively. The scrutiny of data (Table 1 ) further indicated that irrespective of altitudinal gradients, the cultivar Scarlet Spur attained dormancy break at the earliest amongst the selected cultivars in 51.5 days followed by Red Chief ( 52.9 days), Vance Delicious (55.2 days), RedDelicious (56.6 days) and Royal Delicious (58.7 days). The altitudinal variation in calendar days for attaining silver tip stage may be attributed to the higher temperature $\left(1.1\right.$ to $\left.2.3^{\circ} \mathrm{C}\right)$ at altitudinal gradient I as compared to II and III (Figure 1 ). The results are

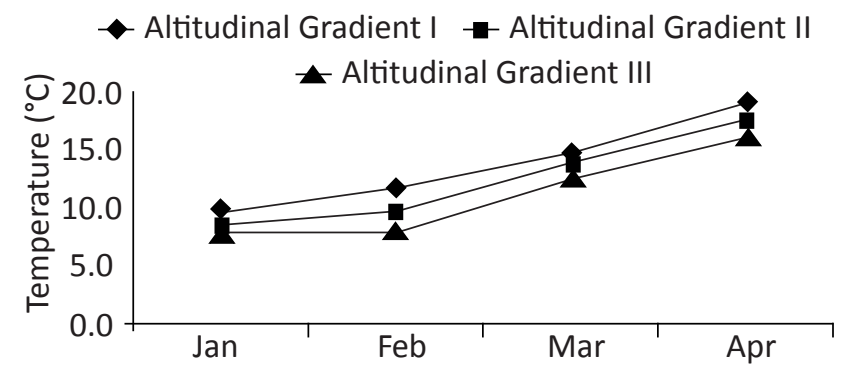

Figure 1: Variation in average temperature at altitudinal gradients during growing season of apple fruit crop in conformity with the findings of Jackson (2003) stating that the growth rate for bud break is determined by prevailing temperatures, so the lower temperature slowed down the rate of development while higher temperature led to a more rapid development.

The present data indicated varietal and location specific differences in attainment of silver tip stage. The observed trend may possibly be because of genetic variations in chilling and heat accumulation requirements of cultivars and altitudinal temperature variations. The results are in line with the findings of Jackson (2003); Wertheim and Schmidt (2005).

\subsection{Effect of altitudinal gradient on calendar days and GDD} required for green tip stage

To evaluate the influence of temperature prior to green tip stage on its timing, calendar days model and heat accumulation (GDD) were used. The use of GDD along with calendar days as a measure of phenophases also facilitated the comparisons to be made across different years for different cultivarsand altitudinal gradients as well.

The days to accomplish green tip stage in apple crop indicated that on average minimum 67.2 days were required at altitudinal gradient I followed by 71.5 and 76.0 days at gradient II and III, respectively. The scrutiny of data further indicated that irrespective of altitudinal gradients, the cultivar Scarlet Spur experienced initiation of green tip stage at the earliest amongst the selected cultivars in 67.1 days followed by Red Chief (67.7days), Vance Delicious (73.8 days), Red Delicious (73.9 days) and Royal Delicious (75.2 days). The altitudinal variation in calendar days for attaining green tip stage may be attributed to the higher temperature $\left(1.4\right.$ to $\left.2.5^{\circ} \mathrm{C}\right)$ at altitudinal gradient I as compared to II and III (Figure 1). The year×cultivarxaltitudinal gradient interaction was also found to be statistically significant and indicated a varying trend from the individual years wherein cultivar Scarlet Spur took minimum duration (62.2 days) at altitudinal gradient I followed by 63.3 days for Red Chief at same gradient. However, highest number of 79.4 days were taken by cultivar Royal Delicious at altitudinal gradient III followed by Red Delicious ( 77.6 days) at same gradient. Donelly et al. (2004) also attributed the significant role of air temperature in influencing the seasonal timing of spring phenophases related to foliage and flowering of various plant species.

The variabilityanalysis carried out through the coefficients of variation revealed a minimum variation for accumulated GDD across the altitudinal gradients and for the growing seasons as well. The variation for GDD was observed lowest at altitudinal gradient I ( $C V=14 \%)$ and highest in altitudinal gradient III ( $\mathrm{CV}=18 \%)$. The rise of 1.3 to $2.6^{\circ} \mathrm{C}$ in temperature was observed for the year 2016 during the attainment of the green tip stage. The high temperature resulted in earlier accumulation of GDD leading to an earlier occurrence of green tip stage in comparison to other altitudinal gradients (Table 2 and 3 ). 
Table 2: Effect of altitude-wise air temperature variations on calendar days for green tip stage in different cultivars of apple fruit crop

\begin{tabular}{|c|c|c|c|c|}
\hline \multirow[t]{2}{*}{ Cultivar } & \multicolumn{4}{|c|}{ Altitudinal gradient } \\
\hline & $\begin{array}{c}1000- \\
1200 \mathrm{~m} \\
\mathrm{amsl}(\mathrm{I})\end{array}$ & $\begin{array}{c}1200- \\
1400 \mathrm{~m} \\
\mathrm{amsl}(\mathrm{II})\end{array}$ & $\begin{array}{c}1400- \\
1600 \mathrm{~m} \\
\text { amsl (III) }\end{array}$ & Mean \\
\hline Royal delicious & 71.1 & 75.1 & 79.4 & 75.2 \\
\hline Red delicious & 70.0 & 74.2 & 77.6 & 73.9 \\
\hline Red chief & 63.3 & 65.6 & 74.3 & 67.7 \\
\hline Vance delicious & 69.3 & 74.4 & 77.8 & 73.8 \\
\hline Scarlet spur & 62.2 & 68.2 & 71.0 & 67.1 \\
\hline Mean & 67.2 & 71.5 & 76.0 & 71.6 \\
\hline \multicolumn{5}{|l|}{$\operatorname{CD}(p=0.05)$} \\
\hline Year & 0.3 & & & \\
\hline Location & 0.4 & & & \\
\hline Cultivar & 0.5 & & & \\
\hline Yearxlocation & 0.5 & & & \\
\hline Year×cultivar & 0.7 & & & \\
\hline $\begin{array}{l}\text { Cultivarx } \\
\text { location }\end{array}$ & 0.8 & & & \\
\hline
\end{tabular}

Year×Cultivar×Altitudinal gradient NS

\subsection{Effect of altitudinal gradient on calendar days and GDD} required for pink bud stage

Numbers of calendar days taken to attain the pink stage varied significantly in all the cultivars and among the altitudinal gradients as well (Table 4). The data indicated that days to accomplish pink bud stage in apple crop indicated that on average minimum 79.0 days were required at altitudinal gradient I followed by 83.0 and 87.8 days at gradient II and III, respectively. The examination of data further indicated that irrespective of altitudinal gradients, the cultivar Scarlet Spur achieved pink bud stage at the earliest amongst the selected cultivars in 76.6 days followed by Red Chief (78.2 days) and Vance Delicious (86.3 days) which was at par with Red Delicious (86.8 days) and Royal Delicious (88.4 days).

The year $\times$ cultivar $\times$ altitudinal gradient interaction was also found to be statistically significant and indicated a similar trend as that of individual years wherein cultivar Scarlet Spur took minimum duration (72.1 days) at altitudinal gradient I followed by 73.7 days for Red Chief at same gradient followed by 76.7 days for Scarlet Spur at altitudinal gradient II. However, highest number of 92.2 days were taken by cultivar Royal Delicious at altitudinal gradient III followed by Red Delicious (90.8 days) at same gradient and 88.6 days by Royal Delicious at altitudinal gradient II. The variations in air temperature among the altitudinal gradients can be attributed to the
Table 3: Effect of altitude-wise air temperature variations on GDD for phenological stages in different cultivars of apple fruit crop

\begin{tabular}{lccccc}
\hline Cultivar & \multicolumn{5}{c}{ Phenological stage } \\
\cline { 2 - 6 } & $\begin{array}{c}\text { Green } \\
\text { tip }\end{array}$ & Pink & Full & Petal & Fruit \\
& & bloom & fall & set \\
\hline Altitudinal gradient I & & & & \\
\hline Royal delicious & 197.0 & 367.6 & 463.6 & 551.9 & 648.2 \\
Red delicious & 184.7 & 345.6 & 439.0 & 526.2 & 629.2 \\
Red chief & 160.1 & 274.2 & 330.8 & 410.1 & 540.2 \\
Vance delicious & 186.3 & 345.4 & 345.3 & 510.8 & 609.9 \\
Scarlet spur & 137.5 & 260.4 & 315.4 & 401.1 & 528.6 \\
SEm \pm & 10.8 & 21.5 & 30.2 & 31.1 & 24.0 \\
CV & 13.9 & 15.1 & 17.8 & 14.5 & 9.1 \\
Altitudinal gradient II & & & & \\
\hline Royal delicious & 185.7 & 361.4 & 455.0 & 551.0 & 650.5 \\
Red delicious & 174.1 & 341.8 & 435.6 & 524.5 & 625.0 \\
Red chief & 110.2 & 240.2 & 289.2 & 391.3 & 527.2 \\
Vance delicious & 160.1 & 324.8 & 357.9 & 511.3 & 616.1 \\
Scarlet spur & 105.7 & 229.7 & 291.5 & 391.9 & 515.2 \\
SEm \pm & 16.5 & 27.1 & 34.8 & 34.2 & 27.4 \\
CV & 25.1 & 20.2 & 21.3 & 16.1 & 10.5 \\
Altitudinal gradient III & & & & \\
\hline Royal delicious & 161.7 & 336.5 & 419.6 & 554.5 & 647.8 \\
Red delicious & 147.9 & 312.3 & 397.1 & 517.8 & 632.8 \\
Red chief & 115.7 & 190.6 & 245.1 & 360.5 & 444.5 \\
Vance delicious & 151.2 & 299.7 & 375.1 & 502.8 & 617.1 \\
Scarlet spur & 93.4 & 196.5 & 258.6 & 370.1 & 463.6 \\
SEm & 12.7 & 30.6 & 36.4 & 40.0 & 44.1 \\
\hline & 21.3 & 25.6 & 24.0 & 19.4 & 17.6 \\
\hline
\end{tabular}

variation in calendar days for achieving pink bud stage by the cultivars. Hanke et al. (2007) also stated that alteration in exogenous factors such as chilling temperature during the winter season resulted in the variations in theflower buds formation.

3.4. Effect of altitudinal gradient on calendar days and GDD required for full bloom stage

The data presented in Table 5 indicated that apple fruit crop growing at different altitudinal gradients exhibited significant variations in all the selected cultivars of apple crop.The days to attain full bloom stage in apple growing regions indicated that on average minimum days of 85.6 were required at altitudinal gradient I followed by 89.7 and 99.0 days at gradient II and III, respectively. The scrutiny of data in table 5 further indicated that irrespective of altitudinal gradients, 
Table 4: Effect of altitude-wise air temperature variations on calendar days for pink bud stage in different cultivars of apple fruit crop

\begin{tabular}{|c|c|c|c|c|}
\hline \multirow[t]{2}{*}{ Cultivar } & \multicolumn{4}{|c|}{ Altitudinal gradient } \\
\hline & $\begin{array}{c}1000- \\
1200 \mathrm{~m} \\
\text { amsl (I) }\end{array}$ & $\begin{array}{c}1200- \\
1400 \mathrm{~m} \\
\text { amsl (II) }\end{array}$ & $\begin{array}{c}1400- \\
1600 \mathrm{~m} \\
\mathrm{amsl}(\mathrm{III})\end{array}$ & Mean \\
\hline Royal delicious & 84.3 & 88.6 & 92.2 & 88.4 \\
\hline Red delicious & 83.0 & 86.6 & 90.8 & 86.8 \\
\hline Red chief & 73.7 & 77.0 & 83.9 & 78.2 \\
\hline Vance delicious & 82.0 & 86.0 & 91.0 & 86.3 \\
\hline Scarlet spur & 72.1 & 76.7 & 80.9 & 76.6 \\
\hline Mean & 79.0 & 83.0 & 87.8 & 83.3 \\
\hline \multicolumn{5}{|l|}{$\mathrm{CD}(p=0.05)$} \\
\hline Year & 0.3 & & & \\
\hline Location & 0.4 & & & \\
\hline Cultivar & 0.5 & & & \\
\hline Yearxlocation & 0.5 & & & \\
\hline Year×cultivar & 0.7 & & & \\
\hline $\begin{array}{l}\text { Cultivarx loca- } \\
\text { tion }\end{array}$ & 0.8 & & & \\
\hline
\end{tabular}

Year×cultivar×altitudinal gradient 1.2

Table 5: Effect of altitude-wise air temperature variations on calendar days for full bloom stage in different cultivars of apple fruit crop

\begin{tabular}{lcccc}
\hline Cultivar & \multicolumn{4}{c}{ Altitudinal gradient } \\
\cline { 2 - 5 } & $\begin{array}{c}1000- \\
1200 \mathrm{~m} \\
\text { amsl (I) }\end{array}$ & $\begin{array}{c}1200- \\
\text { amsl (II) }\end{array}$ & $\begin{array}{c}1400- \\
\text { amsl (III) }\end{array}$ & Mean \\
\hline Royal delicious & 91.8 & 96.4 & 103.4 & 97.2 \\
Red delicious & 89.7 & 94.4 & 101.7 & 95.3 \\
Red chief & 79.1 & 83.0 & 95.6 & 85.9 \\
Vance delicious & 88.1 & 92.6 & 99.8 & 93.5 \\
Scarlet spur & 79.5 & 82.1 & 94.4 & 85.3 \\
Mean & 85.6 & 89.7 & 99.0 & 91.4 \\
CD ( $p=0.05)$ & & & & \\
Year & 0.3 & & & \\
Location & 0.3 & & & \\
Cultivar & 0.4 & & & \\
Yearxlocation & 0.5 & & & \\
Year×cultivar & $\mathrm{NS}$ & & & \\
Cultivarx loca- & 0.8 & & & \\
tion & & & & \\
\hline Year & & & & \\
\hline
\end{tabular}

Year×cultivar×altitudinal gradient 1.1 the cultivar Scarlet Spur experienced full bloom stage at the earliest amongst the selected cultivars in 85.3 days which was at par with Red Chief (85.9 days), followed by Vance Delicious (93.5 days), Red Delicious (95.3 days). Whereas, highest number of days were taken by Royal Delicious (97.2 days). The altitudinal variation in calendar days for attaining full bloom stage may be attributed to the higher temperature at altitudinal gradient I as compared to II and III (Figure 1).The year×cultivarxaltitudinal gradient interaction was also found to be statistically significant and indicated a varying trend from the individual years wherein cultivar Red Chief took minimum of 79.1 days which was at par with Scarlet Spur (79.1 days) at altitudinal gradient I followed by 82.1 days for Scarlet Spur at altitudinal gradient II. However, highest number of 103.4 days were taken by cultivar Royal Delicious at altitudinal gradient III followed by Red Delicious (101.7 days) at same gradient and 96.4 days by Royal Delicious at altitudinal gradient II.

At higher altitude, temperatureregime remained lower as compared to lower altitude as evident from the Figure 1 . The temperature at altitudinal gradient I during the full bloom stage was $1.5^{\circ} \mathrm{C}$ and $2.8^{\circ} \mathrm{C}$ higher than the altitudinal gradient II and III respectively which led to the earliest attainment of bloom stage at altitudinal gradient I. The lower temperature at altitudinal gradient II and III resulted in a delay of 5-8 days and 9-15 days of attainment of full bloom stage with respect to altitudinal gradient I. The results are in line with the study of Chmielewski et al. (2004) who studied response of the beginningof apple tree blossom to the annual deviationsin air temperature at Germany and reported that increased mean temperature and decreased photoperiod caused a shortening of developmental phases of crops with effects on crop yields.

3.5. Effect of altitudinal gradient on calendar days and GDD required for petal fall stage

The perusal of data for the variations in calendar days (Table 6) and GDD (Table 3) for attainment of petal fall stage revealed that days to accomplish petal fall stage in apple crop indicated that on average minimum 92.8 days were required at altitudinal gradient I followed by 98.7 and 105.5 days at gradient II and III, respectively. The scrutiny of data further indicated that irrespective of altitudinal gradients, the cultivar Scarlet Spur experienced initiation of petal fall stage at the earliest amongst the selected cultivars in 92.8 days followed by Red Chief (93.6 days), Vance Delicious (101.6 days), Red Delicious (102.4 days) and Royal Delicious (104.5 days). The altitudinal variation in calendar days for attaining petal fall stage may be attributed tothe higher temperature (1.4 to 2.5 ${ }^{\circ} \mathrm{C}$ ) at altitudinal gradient I as compared to II and III (Figure 1). The year×cultivarxaltitudinal gradient interaction was found to be statistically non-significant and indicated a similar trend as that of the individual years.

Variability in average temperature (Figure 1) at all the altitudinal gradients led to a differential pattern in the attainment of petal fall stage at all the altitudinal gradients. The temperature at altitudinal gradient I during the petal fall 
Table 6: Effect of altitude-wise air temperature variations on calendar days for petal fall stage in different cultivars of apple fruit crop

\begin{tabular}{|c|c|c|c|c|}
\hline \multirow[t]{2}{*}{ Cultivar } & \multicolumn{4}{|c|}{ Altitudinal gradient } \\
\hline & $\begin{array}{c}1000- \\
1200 \mathrm{~m} \\
\text { amsl (I) }\end{array}$ & $\begin{array}{c}1200- \\
1400 \mathrm{~m} \\
\mathrm{amsl}(\mathrm{II})\end{array}$ & $\begin{array}{c}1400- \\
1600 \mathrm{~m} \\
\mathrm{amsl}(\mathrm{III})\end{array}$ & Mean \\
\hline Royal delicious & 98.4 & 104.8 & 110.4 & 104.5 \\
\hline Red delicious & 96.6 & 102.9 & 107.8 & 102.4 \\
\hline Red chief & 86.9 & 92.3 & 101.7 & 93.6 \\
\hline Vance delicious & 95.2 & 102.7 & 106.9 & 101.6 \\
\hline Scarlet spur & 86.8 & 91.0 & 100.5 & 92.8 \\
\hline Mean & 92.8 & 98.7 & 105.5 & 99.0 \\
\hline \multicolumn{5}{|l|}{$\operatorname{CD}(p=0.05)$} \\
\hline Year & 0.3 & & & \\
\hline Location & 0.3 & & & \\
\hline Cultivar & 0.4 & & & \\
\hline Yearxlocation & 0.5 & & & \\
\hline Year×cultivar & 0.6 & & & \\
\hline $\begin{array}{l}\text { Cultivarx loca- } \\
\text { tion }\end{array}$ & 0.8 & & & \\
\hline
\end{tabular}

Year×cultivar×altitudinal gradient NS

stage was 1.7 and $3.0^{\circ} \mathrm{C}$ higher than the altitudinal gradient II and III respectively which lead to the earliest attainment of petal fall stage at altitudinal gradient I. A. variation of 12.7 percent to 19.4 percent in accumulated GDD was observed at different altitudinal gradients.Nanda et al. (1995) also reported similar results for change in phenophasesand showed that for each $1{ }^{\circ} \mathrm{C}$ reduction in temperature, there was an equivalent delay of 1.35 days for cereal plants to reach the first true leaf stage.

3.6. Effect of altitudinal gradient on calendar days and GDD required for fruit set stage

Numbers of calendar days taken to attain the fruit set stage varied significantly in all the cultivars and among the altitudinal gradients as well (Table 7). The analysis of data indicated that on average minimum 100.9 days were required at altitudinal gradient I followed by 106.5 and 111.4 days at gradient II and III, respectively. The examination of data further indicated that irrespective of altitudinal gradients, the cultivar Scarlet Spur achieved fruit set stage at the earliest amongst the selected cultivars in 100.0 days followed by Red Chief (101.2 days) and Vance Delicious (108.7 days) which was at par with Red Delicious (109.8 days). Whereas, highest number of days were taken by cultivar Royal Delicious (111.5 days).The year×cultivar×altitudinal gradient interaction was also found to be statistically significant and indicated a similar trend as that of individual years wherein cultivar Scarlet Spur took minimum duration (95.6 days) at altitudinal gradient I followed by 96.6 days for Red Chief at same gradient followed
Table 7: Effect of altitude-wise air temperature variations on calendar days for fruit set stage in different cultivars of apple fruit crop

\begin{tabular}{|c|c|c|c|c|}
\hline \multirow[t]{2}{*}{ Cultivar } & \multicolumn{4}{|c|}{ Altitudinal gradient } \\
\hline & $\begin{array}{c}1000- \\
1200 \mathrm{~m} \\
\text { amsl (I) }\end{array}$ & $\begin{array}{c}1200- \\
1400 \mathrm{~m} \\
\mathrm{amsl}(\mathrm{II})\end{array}$ & $\begin{array}{c}1400- \\
1600 \mathrm{~m} \\
\text { amsl (III) }\end{array}$ & Mean \\
\hline Royal delicious & 105.7 & 112.5 & 116.4 & 111.5 \\
\hline Red delicious & 103.4 & 111.7 & 114.2 & 109.8 \\
\hline Red chief & 96.6 & 99.6 & 107.3 & 101.2 \\
\hline Vance delicious & 103.0 & 110.5 & 112.7 & 108.7 \\
\hline Scarlet spur & 95.6 & 98.0 & 106.5 & 100.0 \\
\hline Mean & 100.9 & 106.5 & 111.4 & 106.2 \\
\hline \multicolumn{5}{|l|}{$\operatorname{CD}(p=0.05)$} \\
\hline Year & 0.3 & & & \\
\hline Location & 0.4 & & & \\
\hline Cultivar & 0.5 & & & \\
\hline Yearxlocation & 0.5 & & & \\
\hline Year×cultivar & 0.7 & & & \\
\hline $\begin{array}{l}\text { Cultivarx loca- } \\
\text { tion }\end{array}$ & 0.8 & & & \\
\hline
\end{tabular}

Year×cultivar×altitudinal gradient 1.1

by 98.0 days for Scarlet Spur at altitudinal gradient II. However, highest number of 116.4 days were taken by cultivar Royal Delicious at altitudinal gradient III followed by Red Delicious (114.2 days) at same gradient and 112.5 days by Royal Delicious at altitudinal gradient II.

The less temperature difference between the altitudinal gradient I and II resulted in a difference of 6-8 days of attainment between the two gradients as compared to a difference of 7-12 days at altitudinal gradient III. A variation of 6.0 percent to $19.5 \%$ in accumulated GDD was observed at different altitudinal gradients. GDD have a direct influence on the phenological changes during fruitdevelopment in different varieties. Thus it can be attributed that the higher temperature (heat units) increased the growth rate of crop and therefore reduced the duration of fruit set phase at altitudinal gradient I and lowertemperature at altitudinal gradient III accumulated less GDD which might have resultedinto delayed fruit set. The pre-blossom temperatures affect fruit set and subsequent yields and that warmer temperature during flower development has anegative effect on flower viability and fruit set (Rodrigo and Herrero, 2002). The results are in line with the findings of Kanzariaet al. (2015) who investigated the effect of growing degree days onphenology, yield and quality of different mangovarieties under different agro-climaticconditions of Gujarat and observed higher temperature to adversely affect the phenophases. 
3.7. Relationship between air temperature, GDD and phenophases

All phenophases were significant and negatively correlated to the average air temperature from January to April (Table

Table 8: Correlation between average temperature, GDD and phenophases of apple fruit crop during 2015-16

\begin{tabular}{lcc}
\hline Cultivar & \multicolumn{2}{c}{ Altitudinal gradient } \\
\hline Phenological stage & Average temperature $\left({ }^{\circ} \mathrm{C}\right)$ & GDD \\
\hline Silver tip & $-0.992^{*}$ & $-0.994^{*}$ \\
Pink & $-0.902^{*}$ & $-0.999^{*}$ \\
Full bloom & $-0.915^{*}$ & $-0.903^{*}$ \\
Petal fall & $-0.952^{*}$ & $-0.956^{*}$ \\
Fruit set & $-0.967^{*}$ & $-0.984^{*}$ \\
${ }^{*} p<0.05$ & & \\
\hline
\end{tabular}

8). The correlation coefficients ranged between-0.915 and -0.992 , indicating that higher temperature after the winter rest of plants accelerated the developmental processes and finally led to an advanced timing of spring events. Accumulated GDD were found to have a negative correlation (-0.984 to -0.999) with the occurrence of the different phenological stages of apple crop indicating that with increase in GDD the attainment of phenological stages will be advanced. This correlation is in accordance with the fact that the processes involved in bud development, i.e. cell division and growth are temperature dependent and are enhanced by rise in temperature (Hanninen and Tanino, 2011). Matsoukis et al. (2007) also found significantly negative correlation between mean temperature and timing of phenophases in Greece which were also significantly affected by altitudinal variations.

\section{Conclusion}

The investigation indicated that in apple growing regions the warming in the early spring (February-April) by $2-4^{\circ} \mathrm{C}$ at lower elevation caused an advance of 7-13 days in the beginning of phenophases.

\section{References}

Chapman, P.J., Catlin, G.A., 1976. Growth stages in fruit treesfrom dormant to fruit set. In: Plant sciences. New York's Food and Life Sciences Bulletin.

Chmielewski, F.M., Rotzer, T., 2001. Response of tree phenologyto climate change across Europe.Agricultural and Forest Meteorology 108, 101-12.

Chmielewski, F.M., 2003. Phenology and agriculture. Phenology: An Integrative Environmental Science, Schwartz, M.D. (Ed). Kluwer Academic Publishers, 505-522.

Chmielewski, F.M., Muller, A., Bruns, E., 2004. Climate changes and trends in phenology of fruit trees and field crops in Germany 1961-2000. Agriculture and Forest
Meteorology 121, 69-78.

Donelly, A., Jones, M., Sweeney, J., 2004. A review of indicators of climate change for use in Ireland. International Journal of Biometeorology 49, 1-12.

Hanke, M.V., Flachowsky, H., Peil, A., Hattasch, C., 2007. No flower no fruit-genetic potentials to trigger flowering in fruit trees. Genes, Genomes and Genomics 1(1), 1-20.

Hanninen, H., Kramer, K., 2007. A framework for modeling the annual cycle of trees inboreal and temperate regions. Silva Fennica 41(1), 167.

Hanninen, H., Tanino, K., 2011. Tree seasonality in a warming climate. Trends in Plant Science 16(8), 412-16.

Jackson, J.E., 2003. The biology of apples and pears. New York, USA: CambridgeUniversity Press, 488.

Kanzaria, D., Chovatia, R., Polara, N., Varu, D., 2015. Impact of GDD on phenology of mango (Mangifera indica). Indian Journal of Agricultural Sciences 85(8), 1114-17.

Matsoukis, A., Kamoutsis, A., Chronopoulou-Sereli, A., Kiokakis, L., 2007. Evaluation of the phenological behaviour of Malus Domestica Borkh.CV. Starking Delicious in relation to air temperature in Greece. Agr. Med 137, 146-158.

Menzel, A., 2003. Plant phenological anomalies in Germany and their relation to air temperature and NAO.Climate Research 57, 243-263.

Nanda, R., Bhargava, S.C., Rawson, H.M., 1995. Effect of sowing date on rates of leaf appearance, final leaf numbers and areas in Brassica campestris, juncea, B., Napus, B., Carinata, B., Field Crops Research 42, 125-134.

Orlandi, F., Bonofiglio, T., Aguilera, F., Fornaciari, M., 2015. Phenological characteristics of different winegrape cultivars in Central Italy.Vitis 54, 129-136.

Parmesan, C., Yohe, G., 2003. A globally coherent fingerprint of climatechange impacts across natural systems. Nature 421(6918), 37-42.

Rodrigo, J., Herrero, M., 2002. Effects of pre-blossom temperatures on flower development and fruit set in apricot. ScientiaHorticulturae 92, 125-135.

Schwartz, M.D., Ahas, R., Aasa, A., 2006. Onset of spring starting earlier across the Northern Hemisphere.Global Change Biology 12, 343-351.

Singh, M., Bhatia, H.S., 2012. Thermal indices in relation to crop phenology and fruit yield of apple. Mausam 63(3), 449-454.

Vedwan, N., 2006. Culture, Climate and the Environment: Local Knowledge and Perception of Climate Change among Apple Growers in Northwestern India.Journal of Ecological Anthroplogy 10, 4-18.

Wertheim, S., Schmidt, H., 2005. Flowering, pollination and fruit set. (Eds. Webster, A.D., Wertheim, S.J., Tromp, J.). In: Fundamentals of temperate zone tree fruit production, 216-239. Leiden, The Netherlands: Backhuys. 